\title{
ĐÁNH GIÁ TÁC ĐÔNNG MÔI TRƯỜNG VÀ NGUY CƠ XẢY RA SỰ CỐ TRONG QUÁ TRİNH XÂY DỰNG, VẬN HÀNH CÁC DỰ ÂN ĐIỆN MẶT TRỜI
}

\author{
Nguyễn Lệ Mỹ Nhân, Lương Kim Ngân, Phạm Thị Lê Na, Trần Phi Hùng \\ Viện Dầu khí Việt Nam \\ Email: nhannlm.cpse@vpi.pvn.vn \\ https://doi.org/10.47800/PVJ.2021.09-04
}

\section{Tóm tắt}

Bài báo đánh giá tác động của các dự án điện mặt trời quy mô lớn đến môi trường theo từng giai đoạn triển khai dự án, trong đó có vấn đề quản lý và xử lý chất thải từ các tấm pin đã hết thời gian sử dụng, các sự cố trong quá trình xây dựng, vận hành công trình điện mặt trời... Các tác động được nhận diện, đánh giá để làm cơ sở phân tích tính hiệu quả dự án trong bối cảnh phát triển kinh tế gắn với mục tiêu phát triển bền vững môi trường tự nhiên và xã hội. Trên cơ sở đó, nhóm tác giả đề xuất các hướng nghiên cứu giúp các cơ quan quản lý Nhà nước ban hành các quy định cần thiết trong quá trình phê duyệt và quản lý, giám sát môi trường cho các dự án điện mặt trời trong tương lai.

Từ khóa: Năng lượng mặt trời, quang điện, điện mặt trời, đánh giá tác động môi trường.

\section{Giới thiệu}

Dự án điện mặt trời đầu tiên trên thế giới với công suất $1 \mathrm{MW}$ được đưa vào vận hành tại Mỹ năm 1982. Tính đến năm 2020, tổng công suất lắp đặt điện mặt trời trên toàn thế giới đạt khoảng 707,5 GW, trong đó Trung Quốc chiếm hơn $30 \%$ với $253,8 \mathrm{GW}$, tiếp theo là Mỹ với $73,8 \mathrm{GW}$ và Nhật Bản với $67,0 \mathrm{GW}[1,2]$.

Việt Nam có tiềm năng lớn về năng lượng mặt trời, số giờ nắng trong năm đạt khoảng 1.500 - 1.700 giờ ở miền Bắc, $2.000-2.600$ giờ ở miền Trung và miền Nam. Giá trị bức xạ của Việt Nam theo phương ngang dao động trong khoảng rộng từ $897 \mathrm{kWh} / \mathrm{m}^{2} /$ năm đến $2.108 \mathrm{kWh} / \mathrm{m}^{2} / \mathrm{năm}$. Tương ứng với giá trị nhỏ nhất đạt $2,46 \mathrm{kWh} / \mathrm{m}^{2} /$ ngày và lớn nhất là $5,77 \mathrm{kWh} / \mathrm{m}^{2} / \mathrm{ngày}$. Nếu tính từ vĩ tuyến 17 trở xuống, lượng bức xạ mặt trời nhiều và ổn định trong suốt thời gian của năm, giảm khoảng 20\% từ thời kỳ mùa khô sang mùa mưa.

Công nghệ năng lượng mặt trời phục vụ cho sản xuất điện được chia thành 2 loại chính:

- Công nghệ quang điện (Solar Photovoltaic - PV) cho phép biến đổi trực tiếp năng lượng mặt trời thành

Ngày nhận bài: 29/8/2021. Ngày phản biện đánh giá và sửa chữa: 29/8 - 8/9/2021. Ngày bài báo được duyệt đăng: 14/9/2021. điện năng nhờ thiết bị chuyển đổi năng lượng gọi là tấm pin mặt trời (hay tấm quang điện) hoạt động dựa trên quá trình chuyển đổi gọi là hiệu ứng quang điện. Hiệu ứng quang điện giúp sản xuất ra điện năng từ các chất bán dẫn dưới tác dụng của ánh sáng mặt trời. Khi ánh sáng chiếu tới các tế bào quang điện, nó sẽ sản sinh ra điện năng. Khi không có ánh sáng, các tế bào này ngừng sản xuất điện.

- Công nghệ nhiệt điện mặt trời (Concentrating Solar Thermal Power - CSP) sử dụng các hệ thống gương cầu hay gương parabol để hội tụ các tia mặt trời vào các điểm hay trục hội tụ. Nếu cho chất lỏng như nước, dầu... qua vùng hội tụ thì chất lỏng sẽ bị bay hơi ngay cả dưới áp suất cao. Cho hơi này qua các turbine sẽ phát ra điện. Nguyên lý của công nghệ này được sử dụng tương tự trong các nhà máy điện hơi nước cổ điển như các nhà máy nhiệt điện.

Việt Nam đã ban hành Quyết định số 13/2020/QĐ-TTg ngày 6/4/2020 về cơ chế khuyến khích phát triển điện mặt trời. Tính đến nay, các dự án điện mặt trời đã và đang triển khai tại Việt Nam chủ yếu áp dụng công nghệ quang điện (PV) từ các tấm pin mặt trời, gồm các hoạt động chính: Giải phóng mặt bằng, lắp đặt các tấm pin mặt trời (quang điện), đường dây truyền tải điện và hạ tầng dự án; vận hành dự án.

So với năng lượng truyền thống, các dự án điện mặt trời không phát sinh khí thải, nước thải, chất thải rắn có nguy cơ gây ô nhiễm môi trường tiếp nhận. Tuy nhiên, việc 
triển khai các dự án điện mặt trời trên quy mô lớn không tránh khỏi các tác động đến vấn đề sử dụng đất, hệ sinh thái và quản lý/xử lý các tấm pin mặt trời. Bài báo tập trung đánh giá tác động của các dự án năng lượng mặt trời đến môi trường và xã hội theo từng giai đoạn triển khai dự án.

\section{Tác động môi trường đặc thù của dự án điện mặt trời}

\subsection{Hoạt động chuẩn bị dự án và xây dựng/lắp đặt công trình}

\subsection{1. Ảnh hưởng của việc thu hồi đất đến sinh kếngười dân}

Các dựán điện mặt trời quy mô lớn chủ yếu sử dụng đất nông nghiệp

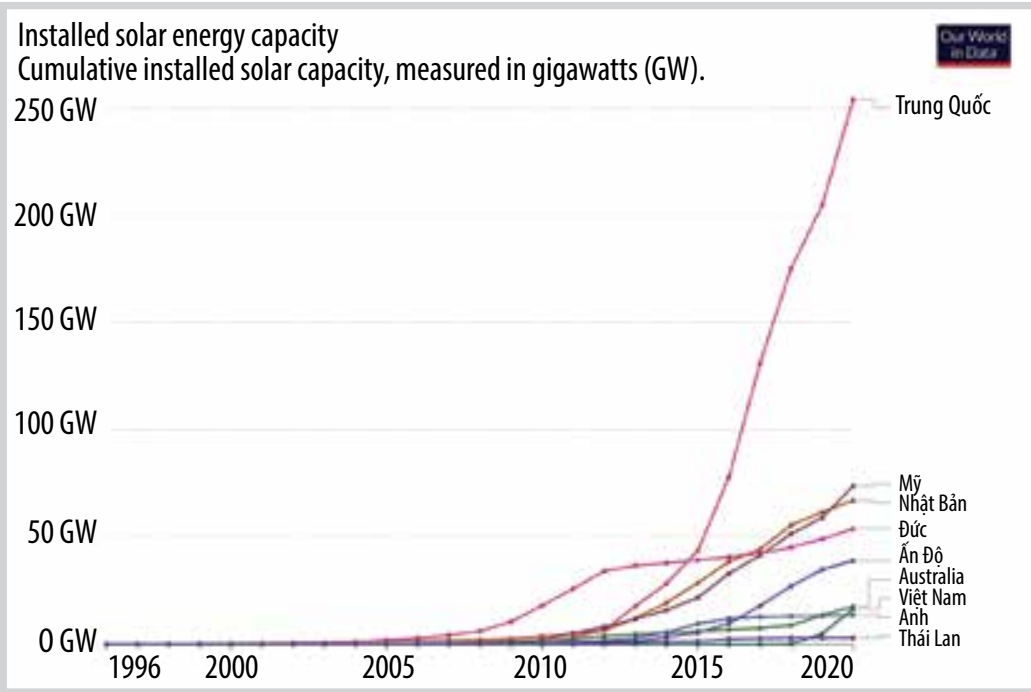

Hình 1. Công suất lắp đặt điện mặt trời của các nước trên thế giới [3]. hoặc đất tự nhiên chưa sử dụng, vị trí xây dựng dự án cần xem xét lựa chọn địa điểm phù hợp, tránh xa các khu vực đông dân cư, các điểm di tích, mang giá trị văn hóa của địa phương và có các chính sách hỗ trợ người dân nhường đất cho dự án nhanh chóng tái lập và ổn định cuộc sống mới.

Các dự án điện mặt trời nổi (lắp đặt nổi phía trên mặt nước nuôi trồng thủy sản, mặt sông hồ, mặt biển gần bờ), điện mặt trời mái nhà (lắp đặt trực tiếp trên mái nhà, công trình) giúp tiết kiệm quỹ đất rất lớn.

\subsection{2. Ảnh hưởng của các chất thải phát sinh từ hoạt động thi công xây dựng}

Chất thải phát sinh từ hoạt động thi công xây dựng dự án điện mặt trời được tổng hợp trong Bảng 2.

Các loại chất thải kể trên chỉ phát sinh trong giai đoạn thi công, xây dựng từ các phương tiện vận tải, máy xúc, máy san ủi... và sinh hoạt của công nhân. Các tác động này chủ yếu phát sinh cục bộ trong phạm vi khu vực dự án.

Bảng 1. Sốliệu vềbức xạ mặt trời tại Việt Nam [4]

\begin{tabular}{|c|c|c|c|}
\hline Vùng & Giờ nắng trong năm & Cường độ bức xạ mặt trời (kWh/m²/ngày) & Ứng dụng \\
\hline Đông Bắc & $1.600-1.750$ & $3,3-4,1$ & Trung bình \\
\hline Tây Bắc & $1.750-1.800$ & $4,1-4,9$ & Trung bình \\
\hline Bắc Trung Bộ & $1.700-2.000$ & $4,6-5,2$ & Tốt \\
\hline Tây Nguyên và Nam Trung Bộ & $2.000-2.600$ & $4,9-5,7$ & Rất tốt \\
\hline Nam Bộ & $2.200-2.500$ & $4,3-4,9$ & Rất tốt \\
\hline Trung bình cả nước & $1.700-2.500$ & 4,6 & Tốt \\
\hline
\end{tabular}

Bảng 2. Các nguồn gây tác động chính có thểxảy ra trong hoạt động thi công xây dựng

\begin{tabular}{|c|c|c|c|}
\hline Loại chất thải & Nguồn gây tác động & Chất ô nhiễm & Tác động \\
\hline Khí thải & $\begin{array}{l}\text { - Hoạt động của phương tiện/thiết } \\
\text { bị phục vụ quá trình thi công xây } \\
\text { dựng. }\end{array}$ & $\begin{array}{l}\text { - Bụi, } \mathrm{COx}, \mathrm{NOx}, \mathrm{SOx}, \mathrm{CH}_{4}, \mathrm{VOC} \text {. } \\
\text { - Tiếng ôn, rung. }\end{array}$ & $\begin{array}{l}\text { - Ảnh hưởng chất lượng không khí xung quanh. } \\
\text { - Tác động đến sức khỏe công nhân và người } \\
\text { dân xung quanh. }\end{array}$ \\
\hline Chất thải lỏng & $\begin{array}{l}\text { - Hoạt động sinh hoạt của công nhân } \\
\text { thi công. } \\
\text { - Hoạt động thi công, lắp đặt các } \\
\text { thiết bị, công trình dựán. }\end{array}$ & $\begin{array}{l}\text { - Nước thải sinh hoạt. } \\
\text { - Nước thải có nguy cơ nhiễm dầu mỡ từ các máy } \\
\text { móc, phương tiện thi công. }\end{array}$ & $\begin{array}{l}\text { - Ảnh hưởng đến chất lượng môi trường } \\
\text { nước. }\end{array}$ \\
\hline Chất thải rắn & $\begin{array}{l}\text { - Sinh hoạt của công nhân thi công. } \\
\text { - Hoạt động xây dựng công trình dự } \\
\text { án. }\end{array}$ & $\begin{array}{l}\text { - Chất thải rắn sinh hoạt. } \\
\text { - Chất thải xây dựng và chất thải nguy hại như } \\
\text { sơn, chất thải dầu mỡ và thùng chứa dầu nhớt, } \\
\text { sơn, hóa chất, giẻ lau dính dầu... }\end{array}$ & $\begin{array}{l}\text { - Ảnh hưởng đến chất lượng nước. } \\
\text { - Ảnh hưởng chất lượng đất. }\end{array}$ \\
\hline
\end{tabular}




\subsection{3. Ảnh hưởng đến đa dạng sinh học}

Điện mặt trời có tác động khác nhau đến hệ sinh thái tự nhiên. Những tác động này liên quan đến một số yếu tố cụ thể, như diện tích và địa hình của khu vực lắp đặt hệ thống điện mặt trời, các hệ sinh thái nhạy cảm và đa dạng sinh hoc.

Ước tính cơ bản của hệ thống tế bào quang điện được sử dụng để tạo ra $1 \mathrm{MW}$ điện là khoảng 3,5 - 10 mẫu Anh (tương đương 0,01-0,04km²) [5]. Như vậy, với các dự án điện mặt trời công suất bình quân $50 \mathrm{MW}$ sẽ cần diện tích lắp đặt khoảng 0,5 - 2 km².

Việc sử dụng diện tích đất để phục vụ cho các dự án điện mặt trời ở quy mô lớn sẽ ảnh hưởng đến đa dạng sinh học của khu vực do làm thay đổi môi trường, cảnh quan và hệ sinh thái khu vực [6]. Tuy nhiên, các dự án điện mặt trời được ưu tiên lựa chọn ở các khu vực đất cằn cỗi, hoang hóa với điều kiện khí hậu khô hạn, nắng nóng hoặc tận dụng lắp đặt nổi trên mặt nước và áp trên mái của các công trình có sẵn nên độ đa dạng sinh học khu vực thường không cao và khả năng tác động đến đa dạng sinh học chỉ ở mức thấp.

\subsection{Hoạt động vận hành}

Nguy cơ ô nhiễm không khí, nước, đất và các chất thải có hại từ dự án điện mặt trời trong quá trình vận hành bình thường gần như không đáng kể, không làm thay đổi tính chất hay chất lượng của môi trường đất, nước và không khí. Nguồn chất thải phát sinh (nếu có) chủ yếu là nước thải vệ sinh và các tấm pin mặt trời bị hư hỏng... khi bảo trì, bảo dưỡng dựán.

\subsubsection{Quản lý/xử lý pin mặt trời bị hư hỏng/hết hạn}

Trong giai đoạn vận hành, các dự án điện mặt trời có nguy cơ phát sinh lượng chất thải lớn là các tấm pin mặt trời bị hư hỏng/hết hạn. Theo số liệu thống kê của các nhà máy điện mặt trời tại Hàn Quốc, tỷ lệ hư hỏng không nhiều, chỉ khoảng 0,005\%/năm. Đối với các tấm pin bị hư hỏng trong thời gian bảo hành sẽ được chủ dự án chuyển cho nhà cung cấp sửa chữa. Đối với các tấm pin hết hạn bảo hành sẽ được chuyển giao cho đơn vị có chức năng xử lý theo quy định.

Với thành phần của pin năng lượng mặt trời, hay pin quang điện (solar panel/module) gồm nhiều tế bào quang điện (solar cell), chủ yếu được chế tạo từ silic dạng tinh thể (đơn tinh thể, đa tinh thể) hoặc màng silic mỏng. Các tế bào quang điện (solar cell) này được ghép lại thành 1 khối để trở thành pin năng lượng mặt trời, thông thường là 60 hoặc 72 tế bào (cell). Chất đóng góp chính vào tổng trọng lượng của module quang điện là thủy tinh (75\%), tiếp theo là polymer (10\%), nhôm (8\%), silicon (5\%), đồng (1\%) và lượng nhỏ bạc, thiếc, chì và các kim loại, linh kiện khác.

Tổ chức IEA Photovoltaic Power Systems Programme - IEA PVPS (Thụy Sĩ) đã khảo sát, nghiên cứu về việc xử lý pin mặt trời đã hết hạn sử dụng từ rất lâu và ở nhiều nước. Kết quả cho thấy, EU đã có quy định tỷ lệ tái chế/tái sử dụng pin mặt trời là 85\%/80\%. Nhật Bản không có quy định cụ thể về việc xử lý các pin mặt trời hết hạn sử dụng, các tấm panel nếu phải thải bỏ thì được xử lý như chất thải rắn thông thường (không phải nguy hại). Trung Quốc, Hàn Quốc cũng đánh giá tương tự [7].

Liên quan đến việc xử lý pin mặt trời, SolarTech (USA) cho biết tuổi thọ các tấm pin mặt trời kéo dài 20 - 30 năm. Nhiều cơ quan kiểm soát ở các bang và liên bang Mỹ đã cho tiến hành thí nghiệm để kiểm tra tính nguy hại đến môi trường, chủ yếu các sản phẩm đều vượt qua các kiểm nghiệm này và các cơ quan này không đưa pin mặt trời vào diện kiểm soát chất thải nguy hại [8]. Nhìn chung, biện pháp xử lý các tấm pin mặt trời hư hỏng/hết hạn hiện nay là tách các thành phần vật liệu cấu tạo nên các tấm panel (kính, cell, kim loại, plastic/polymer) để tái sử dụng, như tái chế các tấm thủy tinh, các cell thì được xử lý hóa học để tái sử dụng sản xuất các cell cho các tấm pin mới có hiệu suất/hiệu quả cao hơn.

Việt Nam chưa có quy định cụ thể về việc phân loại, xử lý các pin mặt trời hết hạn sử dụng, chưa có công bố kiểm nghiệm về tính nguy hại của các tấm pin mặt trời. Mặc dù tuổi thọ của pin điện mặt trời khoảng 20 - 30 năm, song Việt Nam ngay từ bây giờ cần nghiên cứu, tính toán cụ thể phương án xử lý các tấm pin mặt trời hết hạn sử dụng đảm bảo các quy định về môi trường.

\subsubsection{Nước thải từ quá trình rửa tấm pin}

Trong quá trình vận hành bình thường, các dự án điện mặt trời không cần thiết phải vệ sinh thường xuyên hay định kỳ. Tấm pin chủ yếu được làm sạch bằng mưa tự nhiên. Trong trường hợp thời tiết bất lợi, các tấm pin có thể bị ảnh hưởng làm giảm hiệu suất hoạt động, do đó cần được vệ sinh bằng máy chuyên dụng để tiết kiệm thời gian và chi phí nhân công. Nước sau khi rửa pin chủ yếu chỉ chứa bụi, đất, cát, sau đó thấm vào bề mặt đất bên dưới các tấm pin hoặc theo hệ thống thoát nước chung của dự án.

\subsection{3. Ảnh hưởng của điện từ trường}

Trong giai đoạn vận hành, các dự án điện nói chung 
và điện mặt trời nói riêng có nguy cơ gây ảnh hưởng đến sức khỏe của nhân viên vận hành và người dân sống dưới đường dây truyền tải điện do tác động của điện từ trường. Theo các nhà khoa học điện từ trường tần số $50 \mathrm{~Hz}$ khi cường độ điện trường thấp hơn $5 \mathrm{kV} / \mathrm{m}$ thì không ảnh hưởng đến sức khỏe con người. Hệ thống lưới điện của Việt Nam đang vận hành đều có điện từ trường với tần số $50 \mathrm{~Hz}$.

Kết quả khảo sát của Cục Kỹ thuật An toàn Công nghiệp, Bộ Công Thương trong việc kiểm tra, giám sát việc đo cường độ điện trường tại hơn 400 điểm dọc hành lang lưới điện 500 kV và hơn 100 điểm dọc hành lang lưới điện 220 kV cho thấy đối với lưới điện 220 kV, cường độ điện trường luôn có giá trị nhỏ hơn giới hạn quy định $(5 \mathrm{kV} / \mathrm{m})$ theo Nghị định số 14/2014/NĐ-CP ngày 26/2/2014. Còn lưới điện 500 kV, chỉ có 3/400 điểm có chỉ số lớn hơn giới hạn cho phép [10]. Đối với các dự án quang điện, trạm biến áp và các đường dây truyền tải điện thường có cường độ vận hành 110 kV hoặc 220 kV. Kết quả khảo sát điện trường tại các vị trí đo trong các trạm biến áp tham khảo dao động khoảng $0,2-1,4 \mathrm{kV} / \mathrm{m}$, đều thấp hơn so với giá trị quy định $(5 \mathrm{kV} / \mathrm{m})$.

\subsubsection{Tác động đến thị giác}

Dự án điện mặt trời có thể gây ra tác động đến thị giác tùy thuộc vào sơ đồ bố trí tấm pin năng lượng mặt trời và sự phản xạ ánh sáng vào môi trường xung quanh. Một yếu tố quan trọng khác về việc kiểm soát các tác động thị giác là việc sử dụng màu sắc thích hợp trong khi lắp ráp các module pin mặt trời.

Để tránh tác động đến thị giác, các hệ thống năng lượng mặt trời cần được bố trí khoa học ngay trong giai đoạn thiết kế và xây dựng, với quy hoạch và ứng dụng phù hợp.

\section{Các rủi ro, sự cố có thể xảy ra từ hoạt động dự án}

\subsection{Các rủi ro, sự cố môi trường có thể xảy ra trong hoạt động thi công xây dựng}

\subsubsection{Tai nạn lao động}

Với đặc thù công việc thi công nền móng và lắp đặt hệ thống quang điện, trụ điện, vấn đề tai nạn lao động (nhất là các công đoạn làm việc trên cao) rất dễ xảy ra, do đó cần được thực hiện nghiêm túc trong suốt quá trình thi công và lắp đặt thiết bị. Các vấn đề có khả năng phát sinh ra tai nạn lao động gồm:

- Các thiết bị thi công không đảm bảo các điều kiện an toàn, các thiết bị không được kiểm định an toàn lao động theo hướng dẫn;

- Công trường thi công có phương tiện vận chuyển ra vào có thể dẫn đến các tai nạn;

- Không thực hiện tốt các quy định về an toàn lao động khi làm việc với các loại cần cẩu, thiết bị thi công, các loại vật liệu xây dựng chất đống cao...;

- Các tai nạn lao động từ các công tác tiếp cận với thiết bị sử dụng điện;

- Thi công trên cao trong trường hợp thời tiết xấu có thể gây ra tai nạn;

- Trong những ngày mưa thì khả năng gây ra tai nạn lao động có thể tăng cao: đất trơn và dễ lún dẫn đến sự trượt té cho người lao động và các máy móc thiết bị thi công, các sự cố về điện dễ xảy ra hơn...

Xác suất xảy ra sự cố tùy thuộc vào ý thức chấp hành các quy định về an toàn đối với thiết bị cũng như quy trình thi công của nhà thầu và ý thức chấp hành nội quy và quy tắc an toàn lao động của công nhân trong từng trường hợp cụ thể. Đối với các dự án xây dựng, việc tuân thủ nghiêm ngặt quy định về an toàn lao động trong khi thi công và lắp đặt thiết bị; giám sát chặt chẽ và ứng cứu kịp thời có thể giảm đến mức thấp nhất thiệt hại về người và tài sản.

\subsubsection{Nguy cơ cháy nổ}

Sự cố cháy nổ có thể xảy ra trong trường hợp vận chuyển và tồn chứa nhiên liệu phục vụ cho các thiết bị thi công. Sự cố cháy nổ có thể gây nên nhiều thiệt hại về người và của trong quá trình thi công. Có thể xác định các nguyên nhân cụ thể:

- Các kho chứa nguyên nhiên liệu tạm thời phục vụ cho thi công, máy móc, thiết bị kỹ thuật (sơn, xăng, dầu DO...) là các nguồn gây cháy nổ. Khi sự cố xảy ra có thể gây ra thiệt hại nghiêm trọng về người, kinh tế và môi trường;

- Việc sử dụng các thiết bị gia nhiệt trong thi công (cắt, hàn kim loại...) có thể gây ra cháy, bỏng hay tai nạn lao động nếu như không có các dụng cụ bảo hộ cần thiết và ý thức cảnh giác phòng ngừa;

- Quá trình thi công với các thiết bị sử dụng điện có thể gây ra các sự cố chạm, chập điện gây cháy nổ.

\subsubsection{Nguy cơ xảy ra sự cố trong quá trình lắp đặt và đóng điện vận hành}

Công tác lắp đặt và đóng điện vận hành máy biến áp 
tiềm ẩn nguy cơ xảy ra sự cố như: hư hỏng máy biến áp và các trang thiết bị khác của dự án; tai nạn lao động và sự cố cháy nổ. Do đó, cần tuân thủ các quy định về an toàn và quy trình lắp đặt máy biến áp/trạm điện, giám sát chặt chẽ và ứng cứu kịp thời để giảm thiểu nguy cơ xảy ra sự cố.

\subsection{Các rủi ro, sự cố môi trường có thể xảy ra trong hoạt động vận hành}

\subsubsection{Nguy cơ gây cháy nổ}

Quá trình vận hành các dự án điện mặt trời tiềm ẩn nguy cơ xảy ra cháy nổ tại trạm biến áp/trạm điện, đường dây... do sử dụng quá tải, tăng điện áp, chập mạch, do tia lửa tĩnh điện (như sét đánh hoặc đứt dây)... Mặc dù xác suất xảy ra cháy nổ rất thấp, nhưng nếu có sự cố có thể gây thiệt hại rất lớn về người và tài sản, ảnh hưởng đến nguồn cung cấp điện trong khu vực.

\subsubsection{Nguy cơ đứt đường dây}

Trong quá trình vận hành, đường dây đấu nối có thể bị võng hay đứt do bị sự cố thời tiết (như gió bão gây đứt dây, chập điện hoặc nổ trụ) hay bị tác động va đập từ các yếu tố bên ngoài. Khi xảy ra sự cố đứt dây, rơ le tự động trong hệ thống ngắt điện kịp thời nên không ảnh hưởng đến khu vực xung quanh.

Tuy nhiên, trường hợp đứt đường dây tại đoạn giao chéo hay gần với đường giao thông, khu dân cư thì tác động lớn, gây nguy hiểm cho người dân khu vực này.

\subsubsection{Sự cố hư hỏng thiết bị điện}

Trong quá trình vận hành, các tấm pin mặt trời, máy biến áp... có thể hư hỏng do thiết kế/chế tạo kém chất lượng; lắp đặt, vận hành, bảo dưỡng không đúng quy trình; điều kiện vận hành bất lợi hoặc do quá trình sử dụng quá dài.

Các tấm pin mặt trời và thiết bị điện cần được thường xuyên kiểm tra và bảo dưỡng định kỳ để giảm thiểu khả năng xảy ra hư hỏng. Trong trường hợp xảy ra sự cố hư hỏng thiết bị, nhân viên vận hành nhanh chóng thông báo để có biện pháp sửa chữa, xử lý và thay thế kịp thời, đảm bảo vận hành an toàn và liên tục.

\subsubsection{Các rủi ro do thời tiết}

Nhà máy, trạm biến áp và đường dây có thể bị ảnh hưởng do sét đánh trực tiếp hoặc lan truyền gây ra các sự cố cho đường dây. Cường độ dòng điện rất lớn của sét có thể gây đứt, gây hư hỏng các thiết bị điện. Để bảo vệ chống sét đánh trực tiếp vào dây dẫn, toàn bộ khu vực công trình điện được thiết kế các trụ chống sét kể cả dọc đường dây cũng cần được thiết kế treo dây chống sét trên toàn tuyến. Các dự án điện cần được thiết kế chống sét theo quy định hiện hành (cột của đường dây được nối đất, điện trở nối đất) để không xảy ra sự cố này, đồng thời cần chú trọng kiểm tra định kỳ và kiểm tra sau khi có hiện tượng thời tiết bất thường.

Trong quá trình vận hành, các dự án điện có nguy cơ xảy ra sự cố do thiên tai làm hư hỏng các tấm pin và thiết bị, gây mất an toàn điện. Khi mưa bão kéo dài (không có nắng), quá trình cung cấp điện bị gián đoạn sẽ ảnh hưởng đến tình hình sản xuất và cấp điện. Vi vậy, các dự án điện mặt trời cần có kế hoạch dự phòng nhằm ứng phó với các sự cố này, đảm bảo nguồn cung cấp điện an toàn, liên tục cho lưới điện.

\section{Kết luận}

Từ đặc điểm và xu hướng phát triển của các dự án điện mặt trời, cần xem xét các tác động môi trường - xã hội cũng như nhận diện các rủi ro, sự cố có thể phát sinh. Đây là cơ sở để các cơ quan quản lý Nhà nước nhận diện các nguy cơ ảnh hưởng, từ đó đề xuất các giải pháp quản lý, bảo vệ môi trường phù hợp đối với loại dự án này.

Kết quả nghiên cứu cho thấy Việt Nam cần xây dựng các hướng dẫn/quy định về phân loại và xác định tính nguy hại của các tấm pin mặt trời để quản lý/xử lý phù hợp cho các dự án điện mặt trời nghiên cứu các phương pháp thu hồi kim loại nặng từ các tấm pin năng lượng mặt trời để xử lý tái chế và hạn chế lượng chất thải phát sinh.

\section{Tài liệu tham khảo}

[1] BP, "Statistical review of world energy", 2021. [Online]. Available: https://www.bp.com/content/dam/ bp/business-sites/en/global/corporate/pdfs/energyeconomics/statistical-review/bp-stats-review-2021-fullreport.pdf.

[2] Ember, "Global electricity review 2021", 2021. [Online]. Available: https://ember-climate.org/wp-content/ uploads/2021/03/global-electricity-review-2021.pdf.

[3] Our World in Data, "Installed solar energy capacity, 2020". [Online]. Available: https://ourworldindata.org/ grapher/installed-solar-pv-capacity.

[4] Năng lượng Việt Nam, "Cập nhật số liệu khảo sát cường độ bức xạ mặt trời ở Việt Nam", 9/7/2020.

[5] M.M. Hand, S. Baldwin, E. DeMeo, J.M. Reilly, T. Mai, D. Arent, G. Porro, M. Meshek, and D. Sandor, "Renewable 
electricity futures study", National Renewable Energy Laboratory (NREL), 2012, Vol. 4.

[6] R.R Hernandez, S.B Easter, M.L Murphy-Mariscal, F.T. Maestre, M. Tavassoli, E.B. Allen, C.W. Barrows, J. Belnap, R. Ochoa-Hueso, S. Ravi, and M.F. Allen, "Environmental impacts of utility-scale solar energy", Journal Renewable and Sustainable Energy Reviews, 2014, Vol. 29, pp. 766 779. DOI: 10.1016/j.rser.2013.08.041.

[7] IEA - PVPS, "End-of-life management of photovoltaic panels: Trends in PV module recycling technologies". [Online]. Available: https://iea-pvps.
org/wp-content/uploads/2020/01/End_of_Life Management_of_Photovoltaic_Panels_Trends_in_PV_ Module_Recycling_Technologies_by_task_12.pdf.

[8] SolarTech (USA), "What to do when your solar panels expire". [Online]. Available: https:/solartechonline. com/blog/solar-panels-expire/.

[9] Năng lượng Việt Nam, "Pin năng lượng mặt trời hết hạn sử dụng và phương án giải quyết", 12/11/2020.

[10] Báo Nhân Dân, “Giải pháp nào khắc phục ảnh hưởng của điện trường đối với môi sinh", 24/10/2007.

\title{
ASSESSMENT OF ENVIRONMENTAL IMPACTS AND RISK OF INCIDENTS DURING CONSTRUCTION AND OPERATION OF SOLAR POWER PROJECTS
}

\author{
Nguyen Le My Nhan, Luong Kim Ngan, Pham Thi Le Na, Tran Phi Hung \\ Vietnam Petroleum Institute \\ Email: nhannlm.cpse@vpi.pvn.vn
}

\section{Summary}

The article assesses the impacts of large-scale solar power projects on the environment at each stage of project implementation, including the management and treatment of waste from expired solar panels, and incidents occurring during the construction and operation of solar power projects. The impacts are identified and evaluated, which will serve as a basis for analysing the project's effectiveness in the context of economic development associated with the goal of sustainable development of the natural environment and the society. On that basis, the authors propose research directions to help state management agencies promulgate relevant regulations in the process of approval as well as environmental management and monitoring of solar power projects in the future.

Key words: Solar energy, photovoltaic, solar power, environmental impact assessment. 